\title{
Dry Matter and Nitrogen Accumulation as Affected by Nitrogen Fertilization and Seeding Rate in Winter Wheat
}

\author{
Zuliang Shi ${ }^{1,2,{ }^{*}}$, Fei Wang ${ }^{1,2}$, Xiang $\mathrm{Li}^{1}$, Jiuchen Wang ${ }^{1,2}$, Bao Zhe ${ }^{1}$, Renhua Sun ${ }^{1}$, Tao Jia ${ }^{1}$, \\ Chengjun Song ${ }^{1}$ \\ ${ }^{1}$ Rural Energy and Environment Agency, Ministry of Agriculture, Beijing, China \\ ${ }^{2}$ Key Laboratory of Technologies and Models for Cyclic Utilization from Agricultural Resources, Ministry of Agriculture, Beijing, China
}

Email address:

shizuliang1985@163.com(Zuliang Shi)

${ }^{*}$ Corresponding author

\section{To cite this article:}

Zuliang Shi, Fei Wang, Xiang Li, Jiuchen Wang, Bao Zhe, Renhua Sun, Tao Jia, Chengjun Song. Dry Matter and Nitrogen Accumulation as Affected by Nitrogen Fertilization and Seeding Rate in Winter Wheat. American Journal of Agriculture and Forestry.

Vol. 6, No. 3, 2018, pp. 50-59. doi: 10.11648/j.ajaf.20180603.13

Received: April 21, 2018; Accepted: May 8, 2018; Published: May 25, 2018

\begin{abstract}
Objective] Wheat grain yield mainly comes from the accumulation and redistribution of the material after anthesis, the objectives of this study were to assess the contribution of pre- and post-anthesis dry matter, fertilizer nitrogen $(\mathrm{N})$ and soil native $\mathrm{N}$ assimilation to grain yield of winter wheat (Triticum aestivum L.). [Method] Field experiments were conducted to investigate the effects of seeding rates $\left(150,225\right.$ and 300 seeds $\left.\mathrm{m}^{-2}\right)$ at three $\mathrm{N}$ rates $\left(0,150,225 \mathrm{~kg} \mathrm{~N} \mathrm{ha}^{-1}\right)$ on accumulation and remobilization of dry matter and $\mathrm{N}$ from different sources, and grain yield from 2008 to 2010. The experiment sites were located in the Middle and Lower Yangtze River Basin in China. A ${ }^{15} \mathrm{~N}$ micro-plot experiment was designed with the three seeding rates at rate of 150 and $225 \mathrm{~kg} \mathrm{~N} \mathrm{ha}^{-1}$. [Results] The grain yield increased at higher $\mathrm{N}$ rate $\left(225 \mathrm{~kg} \mathrm{~N} \mathrm{ha}^{-1}\right)$ and the optimum seeding rate $\left(225\right.$ seeds m$\left.^{-2}\right)$, and yield differences mainly depended on the number of spikes per unit area and were positively correlated with leaf area index. The higher $\mathrm{N}$ rate and seeding rate increased post-anthesis remobilisation amount of organic matter from leaves and stems and accumulation amount in grain that helped improve grain yield, but decreased remobilization efficiency and the contribution of remobilized dry matter to grain yield. Both post-anthesis $\mathrm{N}$ accumulation and remobilization of $\mathrm{N}$ from the different sources increased with increasing $\mathrm{N}$ rate and seeding rate. For fertilizer $\mathrm{N}$, remobilization efficiency and the contribution of remobilized $\mathrm{N}$ to grain increased with increasing $\mathrm{N}$ rate and seeding rate, whereas for soil $\mathrm{N}$, remobilization efficiency and contribution of $\mathrm{N}$ remobilization to grain $\mathrm{N}(\mathrm{CNRG})$ decreased. Fertilizer $\mathrm{N}$ remobilized to grain more easily than soil N, and top-dressed $\mathrm{N}$ remobilized to grain more easily than basal $\mathrm{N}$. The correlation showed increasing remobilization of fertilizer $\mathrm{N}$ and post-anthesis accumulation of soil $\mathrm{N}$ were beneficial to improving grain yield. [Conclusion] In conclusion, for higher grain yield and nitrogen recovery, combining $\mathrm{N}$ fertilization at $225 \mathrm{~kg} \mathrm{~N} \mathrm{ha}^{-1}$ with seeding rate at $225 \mathrm{seeds} \mathrm{m}^{-2}$ was recommended to wheat management in the Middle and Lower Yangtze River Basin.
\end{abstract}

Keywords: Winter Wheat, Nitrogen Rate, Seeding Rate, Grain Yield, Dry Matter Remobilization, N Uptake, N Remobilization

\section{Introduction}

Rate of nitrogen $(\mathrm{N})$ application is well known to influence grain yield and $\mathrm{N}$ uptake of winter wheat, and studies have clearly demonstrated higher $\mathrm{N}$ rate in wheat could result in higher grain yield, but excessive $\mathrm{N}$ would decrease grain yield and $\mathrm{N}$ uptake [1-2]. Tillage measures have a significant effect on nitrogen uptake by wheat. Compared with conventional farming conditions, no-till conditions can reduce soil and water losses [3], but resulted in a reduce in crop yield [4] and nitrogen uptake significantly [5]. Therefore, no-till is mainly used to control erosion, protect the environment and reduce costs [6]. Plant density will increase with the increase of tillage intensity, seeding rate strongly influence the use of environmental resources by wheat through changing the relative importance of intra-row and inter-row competition for 
light, water and nutrients during crop development [7]. Usually, low seeding rates decreased the number of spikes per unit area, which translated to low grain yield and $\mathrm{N}$ uptake, but seeding rates above the optimum also result in lower grain yield and $\mathrm{N}$ uptake because of increased competition among plants [8-9]. Hence, optimized plant densities are a key to maximizing yields in winter wheat. Carr et al. [10] and Wood et al. [11] found that grain yield of wheat was higher with 250 than with 450 seeds $\mathrm{m}^{-2}$. Conversely, other researchers considered seed densities around 400 seeds $\mathrm{m}^{-2}$ optimal for wheat [12]. However, the optimal seeding rate is vary for the different climatic conditions [13]. Few studies were conducted to verify grain yield and $\mathrm{N}$ uptake in response to the interaction between $\mathrm{N}$ rates and seeding rates in the Middle and Lower Yangtze River Basin.

For grain crops, assimilates to the developing grain originate from two sources i) assimilates derived by photosynthesis and transferred directly to grain, and ii) remobilization of assimilates stored temporarily in vegetative plant parts [14-15]. Zhang et al. [16] showed current assimilates were important for grain growth, the contribution was about 70 97\%. The remobilization of assimilates stored in vegetative parts before anthesis may sustain grain yield when conditions become adverse to photosynthesis and mineral uptake during grain filling [15].

The $\mathrm{N}$ rates and seeding rates influence post-anthesis assimilate accumulation and remobilization. Higher $\mathrm{N}$ fertilization and seeding rate may increase accumulation of dry matter and $\mathrm{N}$ at anthesis, which were highly and positively correlated with both remobilization and yield [7, 16], but higher than optimum $\mathrm{N}$ rates would reduce remobilization of pre-anthesis assimilates and their contribute to grain yield [14]. Fang et al. [13] considered a contribution of stored assimilates to greater grain yield remained uncertain at higher than

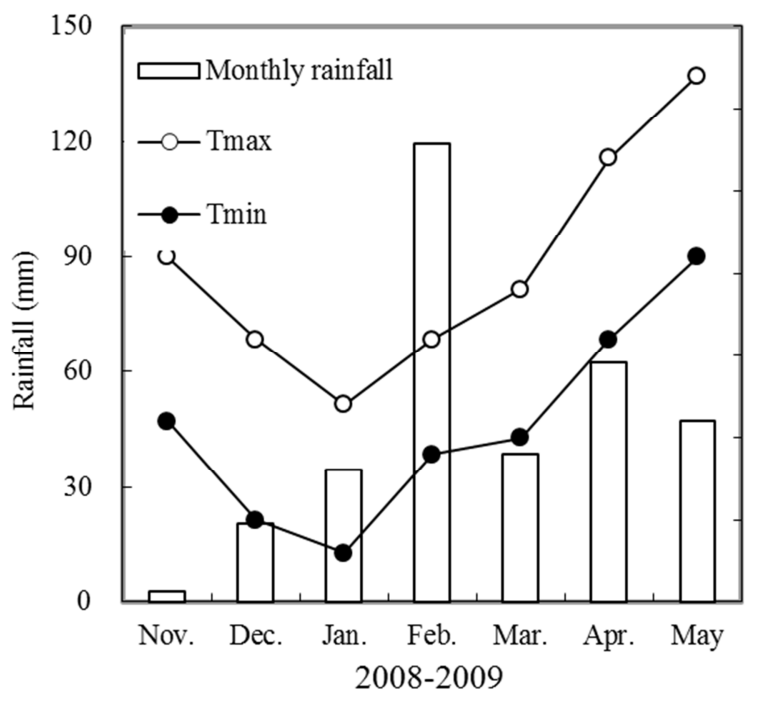

optimal seeding rates. However, little is known about how different sources of $\mathrm{N}$ (either soil or fertilizers) influence dynamics of pre- and post-anthesis assimilate accumulation, remobilization and contribution to grain yield as influenced by the interaction between $\mathrm{N}$ fertilization and seeding rate in the rice-wheat cropping systems.

The objectives of this study were to: 1) examine the effect of different $\mathrm{N}$ fertilization and seeding rates on the wheat grain yield and $\mathrm{N}$ uptake; and 2) assess the contribution of pre- and post-anthesis dry matter and $\mathrm{N}$ accumulation on grain yield.

\section{Materials and Methods}

\subsection{Experimental Site}

Field experiments were conducted at the Jiangsu agronomic experimental station of Nanjing Agricultural University, Nanjing, China $\left(32^{\circ} 04^{\prime} \mathrm{N}\right.$ and $\left.118^{\circ} 76^{\prime} \mathrm{E}\right)$, from 2008 to 2010 . The initial status of the top $0-20 \mathrm{~cm}$ soil layer at the experimental site was as follows: $19 \mathrm{~g} \mathrm{~kg}^{-1}$ organic matter, $0.9 \mathrm{~g} \mathrm{~kg}^{-1}$ total N, $8.9 \mathrm{mg} \mathrm{kg}^{-1}$ nitrate $\mathrm{N}, 4.7 \mathrm{mg} \mathrm{kg}^{-1}$ ammonium N, $15 \mathrm{mg} \mathrm{kg}^{-1}$ Olsen-P, and $97 \mathrm{mg} \mathrm{kg}^{-1}$ available K.

The groundwater table was $100 \mathrm{~cm}$ below the soil surface. The weather data were recorded by an automatic weather station (CM10, Campbell Scientific, USA) at the experimental site. Total rainfall during wheat season was $326 \mathrm{~mm}$ in 2008 2009 and $620 \mathrm{~mm}$ in 2009-2010 (Fig. 1). The distribution of rainfall varied considerably between years. The highest rainfall was in February during the 2008-2009 seasons and in March and April during 2009-2010 seasons. The lowest minimum and maximum temperatures by month were -2 and $7^{\circ} \mathrm{C}$ in January $2008-2009$ and -1 and $8^{\circ} \mathrm{C}$ in January 2009-2010.

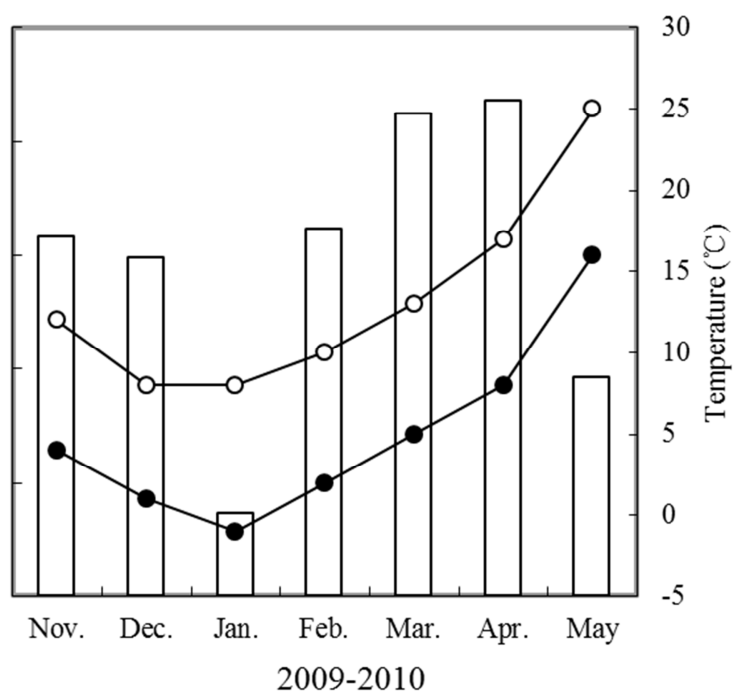

Figure 1. Monthly mean rainfall and mean maximum and minimum temperatures during the two wheat growing season in Nanjing, China.

\subsection{Field Experimental Design}

Experiments were performed in two adjacent fields, grown to wheat over two consecutive seasons. The previous crop was rice (harvested on 20 Oct) with the same $\mathrm{N}$ fertilization in both fields.

The experiments included macro-plot and micro-plot components. The macro-plot experiment was designed as a randomized complete block with three replications. Three $\mathrm{N}$ 
treatments (as urea, 46\% N) were applied: no-N (N0), $150 \mathrm{~kg}$ (N150) and $225 \mathrm{~kg} \mathrm{~N} \mathrm{ha}^{-1}(\mathrm{~N} 225) ; 50 \%$ of the amount was applied at sowing (plowed in) and 50\% at stem elongation (top-dressed) as per standard recommendation on Yangtze Plain (China). Three seeding rate treatments were applied for each N treatment: 150 (D150), 225 (D225) and 300 seeds $\mathrm{m}^{-2}$ (D300). In each season, wheat plots were supplied with P (105 $\mathrm{kg}_{2} \mathrm{O}_{5} \mathrm{ha}^{-1}$, triple superphosphate) and $\mathrm{K}\left(150 \mathrm{~kg} \mathrm{~K}_{2} \mathrm{O} \mathrm{ha}^{-1}\right.$ as potassium chloride) fertilizer at sowing. The plot area was $24 \mathrm{~m}^{2}(4 \mathrm{~m} \times 6 \mathrm{~m})$. The wheat cultivar Yangmai16, with good productivity and adaptability for the middle and lower Yangtze River Basin, was sown in early November in both years, in 25-cm-wide interval rows. Wheat was harvested in early June.

The micro-plots $(0.3 \mathrm{~m} \times 0.3 \mathrm{~m} \times 0.4 \mathrm{~m})$ were set within macro-plots for the treatments $\mathrm{N} 150$ and N225 to monitor uptake and remobilization of $\mathrm{N}$ from different sources. The micro-plots were tamped into macro-plot vertically with the top edge $5 \mathrm{~cm}$ above the ground. All micro-plots received $\mathrm{N}$ application according to the following treatments: (1) $50 \%$ basal $\left({ }^{15} \mathrm{~N}\right.$-labeled) - 50\% top-dressing; or (2) $50 \%$ basal $-50 \%$ top-dressing $\left({ }^{15} \mathrm{~N}\right.$-labeled). There were 72 micro-plots in the field. Ammonium sulfate containing 10.19 atom $\%$ excess ${ }^{15} \mathrm{~N}$ was used (obtained from the Shanghai Chemical Industry Institute). Basal application was mixed with $0-15 \mathrm{~cm}$ soil before sowing, and top dressing was applied at the start of jointing by dissolving fertilizer in $200 \mathrm{~mL}$ of water.

\subsection{Plant Sampling and Analysis}

Three replications were sampled for each treatment at anthesis (171 days after sowing), and maturity (204 days after sowing). Shoots were separated into leaves, culm, chaff, and grain. Fresh samples were oven-dried for 30 minutes at $105^{\circ} \mathrm{C}$ to deactivate enzymes, and then dried at $70^{\circ} \mathrm{C}$ until a constant weight was reached for dry weight determination. The dried samples were milled (100 mesh bead). The total $\mathrm{N}$ content was determined using the semi-micro Kjeldahl method. Natural abundance in the unfertilized macro-plots and the atom $\%{ }^{15} \mathrm{~N}$ in micro-plots were detected using a pattern ZHT-O2 mass spectrometer at the Agroforestry Academy, Chemical Institute of Hebei Province, China.

At anthesis, leaf area was measured using a CI-203 area meter (CID Inc, Camas, Washington, USA) on 20 main tillers in each macro-plot. The instantaneous photosynthetic rate $(\mathrm{Pn})$ was measured using a LI-6400 (LI-COR, Inc., Lincoln, Nebraska, USA) portable gas exchange system from 09:00 h to 11:00 h in 5 flag leaves in each plot. Chlorophyll content (SPAD) was measured with a Chlorophyll Meter (SPAD-502, Minolta, Japan) using the same flag leaves as for the Pn measurement. Mature wheat plants $\left(2 \mathrm{~m}^{2}\right.$ area $)$ were collected in each macro-plot and threshed to determine yield and yield components.

\subsection{Calculations}

Leaf area index $(\mathrm{LAI})=$ leaf area $/$ soil area.

The percentage of $\mathrm{N}$ derived from fertilizer-N (Ndff, \%) was calculated as follows [17]:

$$
\operatorname{Ndff}(\%)=(c-b) /(a-b) \times 100
$$

where $\mathrm{c}$ is the atom $\%{ }^{15} \mathrm{~N}$ abundance in the fertilized plant, a is the atom $\%{ }^{15} \mathrm{~N}$ in the fertilizer and $\mathrm{b}$ is the atom $\%{ }^{15} \mathrm{~N}$ in the unfertilized plant.

Nitrogen uptake, fertilizer recovery and $\mathrm{N}$ efficiency indices were calculated using the following equations:

Plant total $\mathrm{N}$ uptake $=$ plant dry matter weight $\times \mathrm{N}$ concentration $(\%) / 100$;

$\mathrm{N}$ from fertilizer- $\mathrm{N}=($ Total $\mathrm{N}$ uptake $\times \mathrm{Ndff}) / 100$;

Soil native $\mathrm{N}=$ Total $\mathrm{N}$ uptake $-\mathrm{N}$ from fertilizer-N;

Fertilizer-N recovery efficiency $(\mathrm{NRE})=\mathrm{N}$ from fertilizer-N/Total fertilizer $\mathrm{N} \times 100$;

$\mathrm{N}$ agronomic efficiency $(\mathrm{NAE})=($ grain yield at $\mathrm{Nx}-$ grain yield at N0) /applied N at Nx;

$\mathrm{N}$ physiological efficiency $(\mathrm{NPE})=($ grain yield at $\mathrm{Nx}-$ grain yield at $\mathrm{N} 0) /(\mathrm{N}$ uptake at $\mathrm{Nx}-\mathrm{N}$ uptake at $\mathrm{N} 0)$.

The post-anthesis dry matter (DM) and $\mathrm{N}$ accumulation= $\mathrm{DM}$ or $\mathrm{N}$ accumulation of the above-ground plant parts at physiological maturity - DM or $\mathrm{N}$ accumulation of the above-ground plant part at anthesis.

The dry matter and $\mathrm{N}$ remobilization during grain filling were calculated $[12,15]$, as

$\mathrm{DM}$ remobilization $=\mathrm{DM}$ of the above-ground plant part at anthesis - (DM of leaves + culms + chaff at maturity);

$\mathrm{N}$ remobilization $=\mathrm{N}$ accumulation of the above-ground plant part at anthesis $-(\mathrm{N}$ accumulation of leaves + culms + chaff at maturity).

The dry matter and $\mathrm{N}$ remobilization efficiencies were calculated as

$D M$ remobilization efficiency $=(\mathrm{DM}$ remobilized $/ \mathrm{DM}$ of the above-ground plant part at anthesis $) \times 100$;

$\mathrm{N}$ remobilization efficiency $=(\mathrm{N}$ remobilized $/ \mathrm{N}$ accumulated in the above-ground plant part at anthesis $) \times 100$.

The contribution of pre- anthesis DM and $\mathrm{N}$ remobilized to grain were calculated as

$\mathrm{CDMRG}=(\mathrm{DM}$ remobilization $/ \mathrm{DM}$ of grain at maturity $) \times$ 100 ;

$\mathrm{CNRG}=(\mathrm{N}$ remobilization $/ \mathrm{N}$ accumulation of grain at maturity) $\times 100$.

\subsection{Statistical Analysis}

Statistical analysis was conducted using the SAS software package for standard analysis of variance (ANOVA). Treatment means were compared by the least significant difference (LSD) at the 5\% level. The interactions between $\mathrm{N}$ application rate and sowing density, and year variation between the two growth seasons were analyzed by F-value at $5 \%$ and $1 \%$ level. Graphics were prepared using Microsoft Excel.

\section{Results}

\subsection{Grain Yield and Its Components}

F-value $(N \times D)$ analysis showed there were no significant interactions between $\mathrm{N}$ application rate and sowing density, 
but a significant year variation between the two growth seasons except kernel per spike, and the values in 2008-2009 were higher than 2009-2010 season.

Averaged over the seeding rates, grain yield of N225 exceeded by $86 \%$ that of $\mathrm{N} 0$ and by $11 \%$ that of $\mathrm{N} 150$ (means of the two growing seasons) (Table 1). The higher grain yield of $\mathrm{N} 225$ depended on the number of spikes per $\mathrm{m}^{2}(+59$ and $+9 \%)$, the number of kernels per spike $(+19$ and $+7 \%)$, LAI $(+60$ and $+10 \%), \operatorname{Pn}(+24$ and $+3 \%)$ and SPAD value $(+50$ and $+3 \%$ ). Thousand kernel weight (TKW) decreased slightly with increasing $\mathrm{N}$ rate.

Averaged over $\mathrm{N}$ rates, the grain yields obtained with 225 and 300 seeds $\mathrm{m}^{-2}$ were 17 and $16 \%$ higher, respectively, compared with 150 seeds $\mathrm{m}^{-2}$ (Table 1). This increase in grain yield was essential due to the increased the number of spikes per unit area $(+25$ and $+40 \%)$, whereas TKW was not significantly different among the seeding rate treatments in 2009-2010. In contrast, number of kernel per spike decreased from 45 to 39 (means of the two growing seasons) with an increase in seeding rate. Higher seeding rates led to higher LAI $(+16$ and $+3 \%)$ at anthesis, which the values were lower in D150 than D225 and D300 in both seasons. Higher seeding rates decreased flag leaf photosynthesis (Pn) (-9 and -4\%) and SPAD values ( -5 and $-2 \%)$.

Correlation analysis, after combining the data for the 2 years, showed that grain yield was strongly correlated with the number of spikes per $\mathrm{m}^{2}\left(\mathrm{r}=0.915^{* *}\right)$ and LAI $\left(\mathrm{r}=0.973^{* *}\right)$.

Table 1. Spike number, kernel number, kernel weight, LAI, Pn and SPAD value of winter wheat as affected by nitrogen fertilization and seeding rate.

\begin{tabular}{|c|c|c|c|c|c|c|c|c|}
\hline $\begin{array}{l}\text { Growing } \\
\text { season }\end{array}$ & Treatment & $\begin{array}{l}\text { Spike number } \\
\left(\mathbf{m}^{-2}\right)\end{array}$ & $\begin{array}{l}\text { Kernel per spike } \\
\text { (No.) }\end{array}$ & $\begin{array}{l}\text { TKW } \\
\text { (g) }\end{array}$ & $\begin{array}{l}\text { Grain yield } \\
\left(\mathrm{g} \mathrm{m}^{-2}\right)\end{array}$ & $\begin{array}{l}\text { LAI } \\
\left(\mathrm{m}^{2} \mathbf{m}^{-2}\right)\end{array}$ & $\begin{array}{l}\text { Pn }(\mu \mathrm{mol} \\
\left.\mathrm{CO}_{2} \mathrm{~m}^{-2} \mathrm{~s}^{-1}\right)\end{array}$ & $\begin{array}{l}\text { SPAD } \\
\text { value }\end{array}$ \\
\hline \multirow[t]{8}{*}{ 2008 2009 } & Nitrogen rate & & & & & & & \\
\hline & No & $231 \mathrm{~b}$ & $37 \mathrm{~b}$ & $40.7 \mathrm{a}$ & $335 b$ & $2.9 \mathrm{c}$ & $16.7 \mathrm{~b}$ & $36.2 b$ \\
\hline & N150 & $339 a$ & $41 \mathrm{a}$ & $40.0 \mathrm{a}$ & $547 \mathrm{a}$ & $4.6 \mathrm{~b}$ & $21.1 \mathrm{a}$ & $53.1 \mathrm{a}$ \\
\hline & $\mathrm{N} 225$ & $374 a$ & $43 a$ & $38.4 \mathrm{~b}$ & $609 a$ & $5.0 \mathrm{a}$ & $22.0 \mathrm{a}$ & $55.3 \mathrm{a}$ \\
\hline & Seeding rate & & & & & & & \\
\hline & D150 & $254 \mathrm{c}$ & $44 a$ & $40.9 \mathrm{a}$ & $449 \mathrm{~b}$ & $3.9 \mathrm{~b}$ & $20.6 \mathrm{a}$ & $50.3 \mathrm{a}$ \\
\hline & D225 & $325 \mathrm{~b}$ & $40 \mathrm{~b}$ & $40.2 \mathrm{a}$ & $523 a$ & $4.3 \mathrm{a}$ & $19.8 \mathrm{ab}$ & $47.8 \mathrm{~b}$ \\
\hline & D300 & $365 a$ & $37 \mathrm{c}$ & $37.9 \mathrm{~b}$ & $518 \mathrm{a}$ & $4.4 \mathrm{a}$ & $19.3 b$ & $46.4 \mathrm{c}$ \\
\hline F-value & $N \times D$ & $4.6^{*}$ & 0.9 & 2.9 & 0.2 & 0.3 & 0.2 & 1.1 \\
\hline \multirow[t]{8}{*}{ 2009 2010 } & Nitrogen rate & & & & & & & \\
\hline & No & $210 \mathrm{c}$ & $39 \mathrm{c}$ & $37.5 \mathrm{~b}$ & $300 \mathrm{c}$ & $3.0 \mathrm{~b}$ & $17.3 b$ & $35.6 \mathrm{~b}$ \\
\hline & N150 & $303 \mathrm{~b}$ & $44 \mathrm{~b}$ & $38.3 \mathrm{a}$ & $523 b$ & $4.1 \mathrm{a}$ & $19.6 \mathrm{a}$ & $50.9 \mathrm{a}$ \\
\hline & $\mathrm{N} 225$ & $328 a$ & $48 \mathrm{a}$ & $38.1 \mathrm{ab}$ & $573 a$ & $4.5 \mathrm{a}$ & $20.1 \mathrm{a}$ & $52.3 \mathrm{a}$ \\
\hline & Seeding rate & & & & & & & \\
\hline & D150 & $234 \mathrm{c}$ & $47 \mathrm{a}$ & $37.7 \mathrm{a}$ & $418 \mathrm{~b}$ & $3.5 b$ & $20.2 \mathrm{a}$ & $47.0 \mathrm{a}$ \\
\hline & D225 & $287 \mathrm{~b}$ & $44 b$ & $37.9 \mathrm{a}$ & $488 \mathrm{a}$ & $4.0 \mathrm{a}$ & $18.9 \mathrm{~b}$ & $46.5 \mathrm{a}$ \\
\hline & D300 & $320 \mathrm{a}$ & $41 \mathrm{c}$ & $38.1 \mathrm{a}$ & $491 \mathrm{a}$ & $4.1 \mathrm{a}$ & $17.9 \mathrm{c}$ & $45.6 \mathrm{a}$ \\
\hline \multirow[t]{2}{*}{ F-value } & $\mathrm{N} \times \mathrm{D}$ & 2.0 & 0.5 & 0.7 & 2.0 & 0.2 & 0.9 & 0.3 \\
\hline & Year & $180.3^{* *}$ & 3.1 & $1096.8 * *$ & $14.2 * *$ & $9.9 * *$ & $9.6^{* *}$ & $32.9^{* *}$ \\
\hline
\end{tabular}

Means in each column and for each year followed by the same letter are not significantly different at $5 \%$ level. * and ** are significantly different at $5 \%$ and $1 \%$ level. TKW: thousand kernel weight; LAI: leaf area index; Pn: photosynthetic rate; SPAD: chlorophyll content.

\subsection{Accumulation and Remobilization of Dry Matter}

Similar trends in dry matter accumulation and remobilization were observed among treatments in both growing seasons (Table 2). At anthesis as well as at maturity, dry weight of the total above-ground plant parts increased significantly with increasing $\mathrm{N}$ rate. Post-anthesis accumulation of dry matter was the highest in the treatment $\mathrm{N} 225$, increasing by 97 and 12\% compared with N0 and N150, respectively. Dry matter remobilization in N225 was 63 and 7\% higher than that in $\mathrm{N} 0$ and N150, respectively. The ratio of post-anthesis dry matter accumulation to remobilization increased with increasing $\mathrm{N}$ rate. Dry matter remobilization efficiency and the contribution of remobilized dry matter to grain yield (CDMRG) decreased with increasing $\mathrm{N}$ rate, even though the difference was not significant.

At both anthesis and maturity, dry weight increased with an increase of seeding rate, with non-significant differences between D225 and D300 treatments (Table 2). As a result, dry weight increased about $15 \%$ between the lowest and the two higher seeding rates at both stages. Post-anthesis dry matter accumulation and remobilization increased with the optimal seeding rate $\left(225 \mathrm{seed} \mathrm{m}^{-2}\right)$, but there was no difference between the two higher seeding rates. The ratio of post-anthesis dry matter accumulation to remobilization decreased with increasing seeding rate. The dry matter remobilization efficiency and CDMRG were the highest in the seeding rate D225, but there was no significant difference 
among the treatments. Nevertheless, a significant variation was noted between the two growth seasons.

Table 2. Dry matter accumulation (DMA), dry matter remobilization post-anthesis, and contribution of dry matter remobilized to grain yield (CDMRG) of winter wheat as affected by nitrogen fertilization and seeding rate.

\begin{tabular}{|c|c|c|c|c|c|c|c|}
\hline \multirow{2}{*}{$\begin{array}{l}\text { Growth } \\
\text { season }\end{array}$} & \multirow[t]{2}{*}{ Treatment } & $\begin{array}{l}\text { DMA } \\
\text { at anthesis }\end{array}$ & $\begin{array}{l}\text { DMA } \\
\text { at maturity }\end{array}$ & $\begin{array}{l}\text { Post-anthesis } \\
\text { DMA }\end{array}$ & $\begin{array}{l}\text { DM } \\
\text { remobilization }\end{array}$ & $\begin{array}{l}\text { Remobilization } \\
\text { efficiency }\end{array}$ & CDMRG \\
\hline & & $\left(\mathrm{g} \mathrm{m}^{-2}\right)$ & $\left(\mathrm{g} \mathrm{m}^{-2}\right)$ & $\left(\mathrm{g} \mathrm{m}^{-2}\right)$ & $\left(\mathrm{g} \mathrm{m}^{-2}\right)$ & $(\%)$ & $(\%)$ \\
\hline \multirow[t]{8}{*}{$2008 \sim 2009$} & Nitrogen rate & & & & & & \\
\hline & N0 & $593 b$ & $809 c$ & $216 c$ & $119 b$ & $20.0 \mathrm{a}$ & $35.5 \mathrm{a}$ \\
\hline & N150 & $954 a$ & $1317 b$ & $362 b$ & $184 a$ & $19.3 \mathrm{a}$ & $33.7 \mathrm{ab}$ \\
\hline & N225 & $1022 \mathrm{a}$ & $1437 \mathrm{a}$ & $415 a$ & $195 \mathrm{a}$ & $19.1 \mathrm{a}$ & $32.0 \mathrm{~b}$ \\
\hline & Seeding rate & & & & & & \\
\hline & D150 & $825 b$ & $1134 b$ & $309 b$ & $140 \mathrm{~b}$ & $17.0 \mathrm{~b}$ & $31.2 b$ \\
\hline & D225 & $909 a$ & $1249 a$ & $341 \mathrm{a}$ & $182 \mathrm{a}$ & $20.1 \mathrm{a}$ & $34.9 \mathrm{a}$ \\
\hline & D300 & $908 \mathrm{a}$ & $1244 a$ & $336 a$ & $182 \mathrm{a}$ & $20.0 \mathrm{a}$ & $35.1 \mathrm{a}$ \\
\hline \multirow{9}{*}{$\begin{array}{l}\text { F-value } \\
\text { 2009 2010 }\end{array}$} & $\mathrm{N} \times \mathrm{D}$ & 1.5 & 0.8 & 0.6 & 2.0 & 0.3 & 0.3 \\
\hline & Nitrogen rate & & & & & & \\
\hline & N0 & $464 c$ & $679 c$ & $215 b$ & $85 b$ & $18.3 \mathrm{a}$ & $28.3 \mathrm{a}$ \\
\hline & N150 & $738 \mathrm{~b}$ & $1135 b$ & $397 a$ & $126 \mathrm{a}$ & $17.1 \mathrm{a}$ & $24.1 \mathrm{~b}$ \\
\hline & N225 & $824 \mathrm{a}$ & $1261 \mathrm{a}$ & $437 \mathrm{a}$ & $136 \mathrm{a}$ & $16.5 \mathrm{a}$ & $23.8 b$ \\
\hline & Seeding rate & & & & & & \\
\hline & D150 & $607 b$ & $920 \mathrm{~b}$ & $313 b$ & $105 b$ & $17.2 \mathrm{a}$ & $25.0 \mathrm{a}$ \\
\hline & D225 & $710 \mathrm{a}$ & $1073 \mathrm{ab}$ & $362 a$ & $125 \mathrm{a}$ & $17.7 \mathrm{a}$ & $25.7 \mathrm{a}$ \\
\hline & D300 & $751 \mathrm{a}$ & $1117 \mathrm{a}$ & $366 \mathrm{a}$ & $125 \mathrm{a}$ & $16.6 \mathrm{a}$ & $25.4 \mathrm{a}$ \\
\hline \multirow[t]{2}{*}{ F-value } & $\mathrm{N} \times \mathrm{D}$ & 1.8 & 1.4 & 0.2 & 0.5 & 0.1 & 0.2 \\
\hline & Year & $100.8 * *$ & $65.7 * *$ & $48.9 * *$ & $88.6^{* *}$ & $14.8 * *$ & $121.2 * *$ \\
\hline
\end{tabular}

Means in each column and for each year followed by the same letter are not significantly different at 5\% level. * and ** are significantly different at $5 \%$ and $1 \%$ level.

\subsection{Plant N Uptake}

For $\mathrm{N}$ uptake from different sources, the interaction between $\mathrm{N}$ application rate and sowing density was not significant. The similar tendency of plant $\mathrm{N}$ uptake was observed among treatments in both growing seasons, but total $\mathrm{N}$ uptake was lower in 2009-2010 growing season compared to 2008-2009, due to lower uptake of basal fertilizer N (Table 3).

At both anthesis and maturity stages, basal $\mathrm{N}(\mathrm{BN})$, topdressing $\mathrm{N}(\mathrm{DN})$, total fertilizer $\mathrm{N}$ (FN, the sum of BN and $\mathrm{DN})$, soil native $\mathrm{N}(\mathrm{SN})$ and total plant $\mathrm{N}$ uptake (TN, the sum of FN and $\mathrm{SN}$ ) increased significantly with increasing $\mathrm{N}$ rate in both growing seasons, with post-anthesis accumulation of $\mathrm{N}$ from different sources showing the same trend with non-significant differences. Averaged over the $\mathrm{N}$ rates, $\mathrm{N}$ accumulation from different sources at anthesis and maturity increased with increasing seeding rate. Post-anthesis accumulation of $\mathrm{SN}$ and $\mathrm{TN}$ in both growing seasons and post-anthesis accumulation of BN, DN and FN in 2008-2009 growing season increased with increasing seeding rate. But they did not differ among the three seeding rates.

The $\mathrm{N}$ uptake was lower from basal than top-dressed fertilizer. At anthesis and maturity, basal $\mathrm{N}$ uptake was 3.9 and $4.1 \mathrm{~g} \mathrm{~m}^{-2}$ in 2008-2009, and was 0.9 and $1.0 \mathrm{~g} \mathrm{~m}^{-2}$ in 2009-2010. Top-dressed $\mathrm{N}$ uptake was 4.7 and $5.5 \mathrm{~g} \mathrm{~m}^{-2}$ in 2008-2009 and was 4.2 and $5.0 \mathrm{~g} \mathrm{~m}^{-2}$ in 2009-2010, respectively. $\mathrm{N}$ uptake from fertilizer was higher than that from the native soil pool in 2008-2009, the former was 8.6 and $9.6 \mathrm{~g} \mathrm{~m}^{-2}$ at anthesis and maturity; the latter was 5.5 and $6.7 \mathrm{~g} \mathrm{~m}^{-2}$, respectively. However, $\mathrm{N}$ uptake from fertilizer was lower than that from the native soil pool in 2009-2010; fertilizer $\mathrm{N}$ uptake was 5.1 and $5.9 \mathrm{~g} \mathrm{~m}^{-2}$ at anthesis and maturity, and soil $\mathrm{N}$ uptake was 5.9 and $7.1 \mathrm{~g} \mathrm{~m}^{-2}$, respectively; the opposite results in the two growing seasons were chiefly due to lower basal $\mathrm{N}$ uptake in 2009-2010. After anthesis, $\mathrm{N}$ uptake was higher from soil than fertilizer in all treatments, which indicated post-anthesis $\mathrm{N}$ uptake was dominated by soil native $\mathrm{N}$.

Table 3. Plant $N$ uptake from fertilizer ${ }^{15} N$ and soil native $N$ at different development stages in two growing seasons $\left(g m^{-2}\right)$.

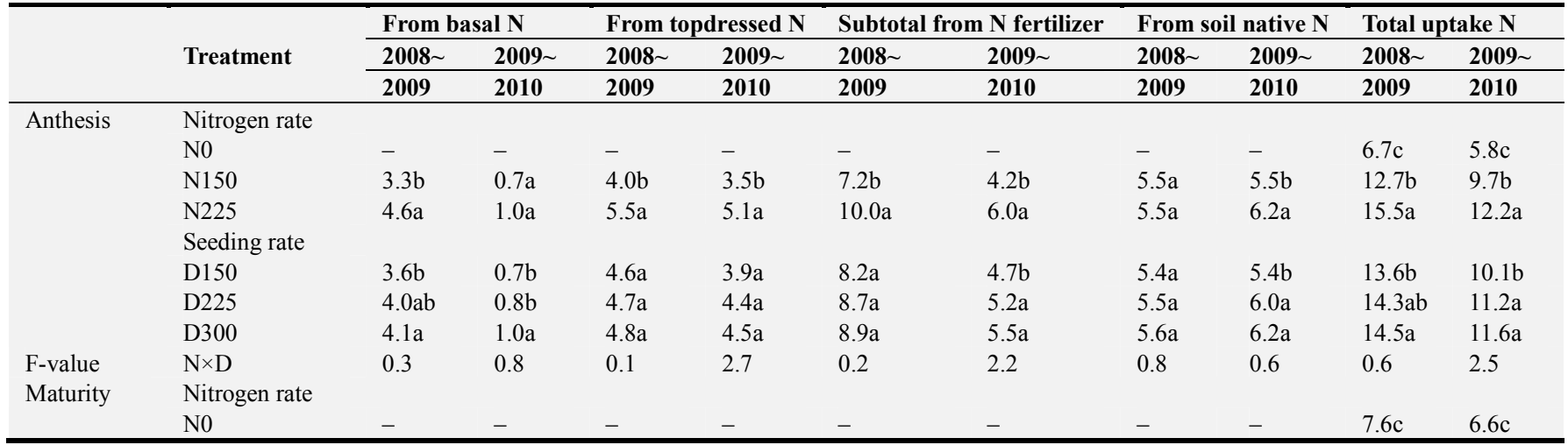




\begin{tabular}{|c|c|c|c|c|c|c|c|c|c|c|c|}
\hline & \multirow[b]{2}{*}{ Treatment } & \multicolumn{2}{|c|}{ From basal N } & \multicolumn{2}{|c|}{ From topdressed N } & \multicolumn{2}{|c|}{ Subtotal from $\mathrm{N}$ fertilizer } & \multicolumn{2}{|c|}{ From soil native $\mathbf{N}$} & \multicolumn{2}{|c|}{ Total uptake N } \\
\hline & & $\begin{array}{l}2008 \sim ~ \\
2009\end{array}$ & $\begin{array}{l}2009 \sim \\
2010\end{array}$ & $\begin{array}{l}2008 \sim \\
2009\end{array}$ & $\begin{array}{l}2009 \sim \\
2010\end{array}$ & $\begin{array}{l}2008 \sim \\
2009\end{array}$ & $\begin{array}{l}2009 \sim \\
2010\end{array}$ & $\begin{array}{l}2008 \sim \\
2009\end{array}$ & $\begin{array}{l}2009 \sim \\
2010\end{array}$ & $\begin{array}{l}2008 \sim \\
2009\end{array}$ & $\begin{array}{l}2009 \sim \\
2010\end{array}$ \\
\hline \multirow{12}{*}{$\begin{array}{l}\text { F-value } \\
\text { Post- } \\
\text { anthesis }\end{array}$} & $\begin{array}{l}\text { N150 } \\
\text { N225 } \\
\text { Seeding rate }\end{array}$ & $\begin{array}{l}3.4 \mathrm{~b} \\
4.7 \mathrm{a}\end{array}$ & $\begin{array}{l}0.8 \mathrm{a} \\
1.1 \mathrm{a}\end{array}$ & $\begin{array}{l}4.6 \mathrm{~b} \\
6.4 \mathrm{a}\end{array}$ & $\begin{array}{l}4.2 \mathrm{~b} \\
5.8 \mathrm{a}\end{array}$ & $\begin{array}{l}8.0 \mathrm{~b} \\
11.1 \mathrm{a}\end{array}$ & $\begin{array}{l}4.9 \mathrm{~b} \\
6.9 \mathrm{a}\end{array}$ & $\begin{array}{l}6.6 \mathrm{a} \\
6.9 \mathrm{a}\end{array}$ & $\begin{array}{l}6.5 \mathrm{a} \\
7.7 \mathrm{a}\end{array}$ & $\begin{array}{l}14.6 \mathrm{~b} \\
17.9 \mathrm{a}\end{array}$ & $\begin{array}{l}11.4 \mathrm{~b} \\
14.5 \mathrm{a}\end{array}$ \\
\hline & D150 & $3.7 \mathrm{c}$ & $0.8 \mathrm{a}$ & $5.4 \mathrm{a}$ & $4.7 \mathrm{~b}$ & $9.1 \mathrm{~b}$ & $5.5 \mathrm{a}$ & $6.6 \mathrm{~b}$ & $6.5 \mathrm{c}$ & $15.7 \mathrm{~b}$ & $12.0 \mathrm{~b}$ \\
\hline & D225 & $4.1 b$ & $0.9 \mathrm{a}$ & $5.5 \mathrm{a}$ & $5.1 \mathrm{a}$ & $9.6 \mathrm{ab}$ & $6.0 \mathrm{a}$ & $6.8 \mathrm{ab}$ & $7.3 \mathrm{~b}$ & $16.4 \mathrm{ab}$ & $13.3 \mathrm{a}$ \\
\hline & D300 & $4.4 \mathrm{a}$ & $1.1 \mathrm{a}$ & $5.5 \mathrm{a}$ & $5.2 \mathrm{a}$ & $9.9 \mathrm{a}$ & $6.2 \mathrm{a}$ & $6.9 \mathrm{a}$ & $7.5 \mathrm{a}$ & $16.8 \mathrm{a}$ & $13.7 \mathrm{a}$ \\
\hline & $\mathrm{N} \times \mathrm{D}$ & 0.3 & 0.4 & 0.8 & 1.6 & 0.5 & 2.6 & 1.5 & 1.3 & 0.9 & $4.4^{*}$ \\
\hline & Nitrogen rate & & & & & & & & & & \\
\hline & No & - & - & - & - & - & - & - & - & $0.8 \mathrm{~b}$ & $0.9 \mathrm{~b}$ \\
\hline & N150 & $0.2 \mathrm{a}$ & $0.1 \mathrm{a}$ & $0.7 \mathrm{a}$ & $0.7 \mathrm{a}$ & $0.8 \mathrm{a}$ & $0.8 \mathrm{a}$ & $1.1 \mathrm{a}$ & $1.0 \mathrm{a}$ & $1.9 \mathrm{a}$ & $1.7 \mathrm{a}$ \\
\hline & $\begin{array}{l}\text { N225 } \\
\text { Seeding rate }\end{array}$ & $0.2 \mathrm{a}$ & $0.1 \mathrm{a}$ & $0.9 \mathrm{a}$ & $0.8 \mathrm{a}$ & $1.1 \mathrm{a}$ & $0.9 \mathrm{a}$ & $1.3 \mathrm{a}$ & $1.5 \mathrm{a}$ & $2.4 \mathrm{a}$ & $2.3 \mathrm{a}$ \\
\hline & $\mathrm{D} 150$ & $0.1 \mathrm{a}$ & $0.1 \mathrm{a}$ & $0.8 \mathrm{a}$ & $0.7 \mathrm{a}$ & $0.9 \mathrm{a}$ & $0.8 \mathrm{a}$ & $1.2 \mathrm{a}$ & $1.1 \mathrm{a}$ & $2.1 \mathrm{a}$ & $1.9 \mathrm{a}$ \\
\hline & D225 & $0.1 \mathrm{a}$ & $0.1 \mathrm{a}$ & $0.9 \mathrm{a}$ & $0.7 \mathrm{a}$ & $0.9 \mathrm{a}$ & $0.8 \mathrm{a}$ & $1.2 \mathrm{a}$ & $1.2 \mathrm{a}$ & $2.1 \mathrm{a}$ & $2.0 \mathrm{a}$ \\
\hline & D300 & $0.2 \mathrm{a}$ & $0.1 \mathrm{a}$ & $0.9 \mathrm{a}$ & $0.7 \mathrm{a}$ & $1.0 \mathrm{a}$ & $0.8 \mathrm{a}$ & $1.3 \mathrm{a}$ & $1.4 \mathrm{a}$ & $2.3 \mathrm{a}$ & $2.1 \mathrm{a}$ \\
\hline F-value & $\mathrm{N} \times \mathrm{D}$ & 0.1 & 0.7 & 1.4 & 0.1 & 1.3 & 0.0 & 0.3 & 0.1 & 0.0 & 0.0 \\
\hline
\end{tabular}

Means in each column and for each year followed by the same letter are not significantly different at $5 \%$ level. * is significantly different at $5 \%$ level.

\section{4. $N$ Remobilization}

The interaction between $\mathrm{N}$ application rate and sowing density was not significant for $\mathrm{N}$ remobilization amount, remobilization efficiency and CNRG. In both growing seasons, remobilization of $\mathrm{N}$ from different sources increased with increasing $\mathrm{N}$ rate and increasing seeding rate, but $\mathrm{N}$ remobilization efficiencies and CNRG of $\mathrm{N}$ from different sources were different among treatments. Remobilization efficiency and CNRG of fertilizer $\mathrm{N}$ (basal $\mathrm{N}$, top-dressed $\mathrm{N}$ and total fertilizer $\mathrm{N}$ ) increased with increasing $\mathrm{N}$ rate and increasing seeding rate. In contrast, remobilization efficiencies and CNRG of SN decreased with increasing $\mathrm{N}$ rate, resulting in decreased remobilization efficiencies and CNRG of TN. Increasing seeding rate increased remobilization efficiencies of $\mathrm{SN}$, but $\mathrm{CNRG}$ of $\mathrm{SN}$ increased first and then decreased, which led to the same tendency in
CNRG of TN (Table 4).

$\mathrm{N}$ remobilization amount, remobilization efficiency and CNRG of basal $\mathrm{N}$ were, respectively, $2.7 \mathrm{~g} \mathrm{~m}^{-2}, 70.0 \%$ and $24.9 \%$ in $2008-2009$ and $1.0 \mathrm{~g} \mathrm{~m}^{-2}, 72.3 \%$ and $9.9 \%$ in 2009-2010. The values of top-dressed $\mathrm{N}$ were, respectively, $3.4 \mathrm{~g} \mathrm{~m}^{-2}, 71.5 \%, 30.5 \%$ in $2008-2009$ and $3.3 \mathrm{~m}^{-2}, 77.7 \%$, $33.5 \%$ in 2009-2010. This indicated that top-dressed $\mathrm{N}$ remobilized to grain more easily than basal N. N remobilization amount, remobilization efficiency and CNRG of total fertilizer $\mathrm{N}$ were, respectively, $6.1 \mathrm{~g} \mathrm{~m}^{-2}, 70.8 \%, 55.4 \%$ in 2008-2009 and $4.3 \mathrm{~g} \mathrm{~m}^{-2}, 76.3 \%$ and $43.4 \%$ in $2009-2010$; whereas the values of soil native $\mathrm{N}$ were, respectively, $2.7 \mathrm{~g}$ $\mathrm{m}^{-2}, 49.3 \%, 24.8 \%$ in $2008-2009$ and $3.5 \mathrm{~m}^{-2}, 60.1 \%, 36.1 \%$ in 2009-2010, indicating that fertilizer $\mathrm{N}$ remobilized to grain more easily than soil $\mathrm{N}$.

Table 4. The $N$ remobilization and contribution of $N$ remobilization to grain $N(C N R G)$ in winter wheat as affected by nitrogen fertilization and seeding rate.

\begin{tabular}{|c|c|c|c|c|c|c|c|c|c|c|c|}
\hline \multirow{3}{*}{ Item } & \multirow{3}{*}{ Treatment } & \multicolumn{2}{|c|}{ From basal N } & \multicolumn{2}{|c|}{ From topdressed N } & \multicolumn{2}{|c|}{ Subtotal from $\mathbf{N}$ fertilizer } & \multicolumn{2}{|c|}{ From soil native $\mathbf{N}$} & \multicolumn{2}{|c|}{ Total uptake $\mathbf{N}$} \\
\hline & & 2008 & 2009 & 2008 & 2009 & 2008 & 2009 & 2008 & 2009 & 2008 & 2009 \\
\hline & & 2009 & 2010 & 2009 & 2010 & 2009 & 2010 & 2009 & 2010 & 2009 & 2010 \\
\hline \multirow{6}{*}{$\begin{array}{l}\mathrm{N} \\
\text { remobilization } \\
\text { amount } \\
\left(\mathrm{g} \mathrm{m}^{-2}\right)\end{array}$} & $\begin{array}{l}\text { Nitrogen rate } \\
\text { N0 }\end{array}$ & - & - & - & - & - & - & - & - & $4.4 c$ & $4.0 \mathrm{c}$ \\
\hline & N150 & $2.3 b$ & $0.8 \mathrm{a}$ & $2.8 \mathrm{~b}$ & $2.6 b$ & $5.1 \mathrm{~b}$ & $3.5 \mathrm{~b}$ & $2.8 \mathrm{a}$ & $3.5 \mathrm{a}$ & $8.0 \mathrm{~b}$ & $7.0 \mathrm{~b}$ \\
\hline & $\begin{array}{l}\text { N225 } \\
\text { Seeding rate }\end{array}$ & $3.2 \mathrm{a}$ & $1.1 \mathrm{a}$ & $3.9 \mathrm{a}$ & $4.0 \mathrm{a}$ & $7.1 \mathrm{a}$ & $5.1 \mathrm{a}$ & $2.6 \mathrm{a}$ & $3.6 \mathrm{a}$ & $9.7 \mathrm{a}$ & $8.7 \mathrm{a}$ \\
\hline & D150 & $2.4 \mathrm{~b}$ & $0.8 \mathrm{~b}$ & $3.1 \mathrm{~b}$ & $3.0 \mathrm{~b}$ & $5.6 \mathrm{~b}$ & $3.8 \mathrm{~b}$ & $2.4 \mathrm{a}$ & $3.2 \mathrm{a}$ & $8.0 \mathrm{~b}$ & $7.0 \mathrm{~b}$ \\
\hline & D225 & $2.8 \mathrm{a}$ & $1.0 \mathrm{ab}$ & $3.4 \mathrm{ab}$ & $3.4 \mathrm{ab}$ & $6.2 \mathrm{a}$ & $4.4 \mathrm{a}$ & $2.8 \mathrm{a}$ & $3.7 \mathrm{a}$ & $9.1 \mathrm{ab}$ & $8.0 \mathrm{a}$ \\
\hline & D300 & $2.9 \mathrm{a}$ & $1.1 \mathrm{a}$ & $3.5 \mathrm{a}$ & $3.5 \mathrm{a}$ & $6.5 \mathrm{a}$ & $4.7 \mathrm{a}$ & $2.9 \mathrm{a}$ & $3.7 \mathrm{a}$ & $9.4 \mathrm{a}$ & $8.4 \mathrm{a}$ \\
\hline \multirow{9}{*}{$\begin{array}{l}\text { F-value } \\
\mathrm{N} \\
\text { remobilization } \\
\text { efficiency } \\
(\%)\end{array}$} & $N \times D$ & 0.1 & 0.5 & 0.1 & 2.2 & 0.1 & 1.5 & 0.3 & 0.4 & 0.4 & 0.2 \\
\hline & Nitrogen rate & & & & & & & & & & \\
\hline & No & - & - & - & - & - & - & - & - & $65.0 \mathrm{a}$ & $68.9 a$ \\
\hline & N150 & $70.6 \mathrm{a}$ & $71.3 \mathrm{a}$ & $70.8 \mathrm{a}$ & $76.6 \mathrm{a}$ & $70.7 \mathrm{a}$ & $75.3 \mathrm{a}$ & $51.7 \mathrm{a}$ & $63.3 \mathrm{a}$ & $62.5 \mathrm{a}$ & $68.8 \mathrm{a}$ \\
\hline & N225 & $69.6 \mathrm{a}$ & $73.1 \mathrm{a}$ & $71.9 \mathrm{a}$ & $78.5 \mathrm{a}$ & $70.9 \mathrm{a}$ & $77.1 \mathrm{a}$ & $47.0 \mathrm{~b}$ & $57.1 \mathrm{a}$ & $62.4 \mathrm{a}$ & $67.4 \mathrm{a}$ \\
\hline & Seeding rate & & & & & & & & & & \\
\hline & D150 & $67.7 \mathrm{a}$ & $71.9 \mathrm{a}$ & $67.9 \mathrm{~b}$ & $76.2 b$ & $67.8 b$ & $74.9 \mathrm{a}$ & $45.2 b$ & $59.3 \mathrm{a}$ & $58.9 \mathrm{a}$ & $66.9 \mathrm{a}$ \\
\hline & D225 & $71.0 \mathrm{a}$ & $71.9 \mathrm{a}$ & $71.7 \mathrm{a}$ & $78.1 \mathrm{a}$ & $71.4 \mathrm{a}$ & $76.6 \mathrm{a}$ & $51.0 \mathrm{a}$ & $60.4 \mathrm{a}$ & $63.5 \mathrm{a}$ & $68.3 \mathrm{a}$ \\
\hline & D300 & $71.2 \mathrm{a}$ & $73.5 \mathrm{a}$ & $74.5 \mathrm{a}$ & $78.9 \mathrm{a}$ & $73.0 \mathrm{a}$ & $77.5 \mathrm{a}$ & $51.8 \mathrm{a}$ & $60.3 \mathrm{a}$ & $64.8 \mathrm{a}$ & $68.8 \mathrm{a}$ \\
\hline \multirow{5}{*}{$\begin{array}{l}\text { F-value } \\
\text { CNRG } \\
(\%)\end{array}$} & $N \times D$ & 0.2 & 0.1 & 0.3 & 0.4 & 0.3 & 0.2 & 0.1 & 0.1 & 0.3 & 0.2 \\
\hline & Nitrogen rate & & & & & & & & & & \\
\hline & N0 & - & - & - & - & - & - & - & - & $83.8 \mathrm{a}$ & $82.2 \mathrm{a}$ \\
\hline & N150 & $23.4 \mathrm{a}$ & $9.4 \mathrm{a}$ & $28.3 \mathrm{a}$ & $30.5 b$ & $51.7 \mathrm{~b}$ & $39.9 \mathrm{a}$ & $28.1 \mathrm{a}$ & $40.4 \mathrm{a}$ & $80.5 a$ & $80.2 \mathrm{a}$ \\
\hline & N225 & $26.2 \mathrm{a}$ & $10.4 \mathrm{a}$ & $32.4 \mathrm{a}$ & $36.2 \mathrm{a}$ & $58.6 \mathrm{a}$ & $46.6 \mathrm{a}$ & $21.5 \mathrm{a}$ & $32.5 \mathrm{~b}$ & $80.1 \mathrm{a}$ & $79.0 \mathrm{a}$ \\
\hline
\end{tabular}




\begin{tabular}{|c|c|c|c|c|c|c|c|c|c|c|c|}
\hline \multirow[b]{2}{*}{ Item } & \multirow[b]{2}{*}{ Treatment } & \multicolumn{2}{|c|}{ From basal N } & \multicolumn{2}{|c|}{ From topdressed N } & \multicolumn{2}{|c|}{ Subtotal from $\mathbf{N}$ fertilizer } & \multicolumn{2}{|c|}{ From soil native $\mathbf{N}$} & \multicolumn{2}{|c|}{ Total uptake $\mathrm{N}$} \\
\hline & & $\begin{array}{l}2008 \sim \\
2009\end{array}$ & $\begin{array}{l}2009 \sim \\
2010\end{array}$ & $\begin{array}{l}2008 \sim ~ \\
2009\end{array}$ & $\begin{array}{l}2009 \sim \\
2010\end{array}$ & $\begin{array}{l}2008 \sim \\
2009\end{array}$ & $\begin{array}{l}2009 \sim \\
2010\end{array}$ & $\begin{array}{l}2008 \sim \\
2009\end{array}$ & $\begin{array}{l}2009 \sim \\
2010\end{array}$ & $\begin{array}{l}2008 \sim ~ \\
2009\end{array}$ & $\begin{array}{l}2009 \sim \\
2010\end{array}$ \\
\hline & $\begin{array}{l}\text { Seeding rate } \\
\text { D150 }\end{array}$ & $24.2 \mathrm{a}$ & $9.1 \mathrm{a}$ & $31.0 \mathrm{a}$ & $33.7 \mathrm{a}$ & $55.2 \mathrm{a}$ & $42.7 \mathrm{a}$ & $24.1 \mathrm{a}$ & $36.1 \mathrm{a}$ & 79.3a & $78.8 \mathrm{a}$ \\
\hline & D225 & $25.3 \mathrm{a}$ & $9.8 \mathrm{a}$ & $30.4 \mathrm{a}$ & $33.8 \mathrm{a}$ & $55.8 \mathrm{a}$ & $43.6 \mathrm{a}$ & $25.27 \mathrm{a}$ & $36.3 \mathrm{a}$ & $80.9 \mathrm{a}$ & $79.9 \mathrm{a}$ \\
\hline & D300 & $25.2 \mathrm{a}$ & $10.8 \mathrm{a}$ & $30.3 \mathrm{a}$ & $33.5 \mathrm{a}$ & $55.5 \mathrm{a}$ & $44.3 \mathrm{a}$ & $24.9 \mathrm{a}$ & $35.5 \mathrm{a}$ & $80.5 \mathrm{a}$ & $79.8 \mathrm{a}$ \\
\hline F-value & $\mathrm{N} \times \mathrm{D}$ & 0.0 & 0.2 & 0.2 & 0.3 & 0.0 & 0.3 & 0.1 & 0.2 & 0.0 & 0.1 \\
\hline
\end{tabular}

Means in each column and for each year followed by the same letter are not significantly different at $5 \%$ level.

\subsection{Correlation Between Grain Yield and Remobilization of Dry Matter and Nitrogen}

Pooling the data for the 2 years, the correlation coefficients regarding dry matter and $\mathrm{N}$ accumulation during grain filling period, dry matter and $\mathrm{N}$ remobilization with grain yield were shown in Table 5. Both post-anthesis dry matter accumulation and dry matter remobilization were strongly positive correlated with grain yield, but there was inconsistency among
$\mathrm{N}$ from different sources. For fertilizer $\mathrm{N}(\mathrm{BN}, \mathrm{DN}$ and $\mathrm{FN})$ and total $\mathrm{N}$, grain yield was positively correlated with remobilization amount, but not with post-anthesis accumulation; but for $\mathrm{SN}$, grain yield was only positively correlated with post-anthesis accumulation. Thus, increasing post-anthesis accumulation and remobilization of dry matter, remobilization of fertilizer $\mathrm{N}$ and post-anthesis accumulation of soil $\mathrm{N}$ were beneficial to improving grain yield.

Table 5. Correlation analysis of dry matter, nitrogen accumulation and remobilization with grain yield.

\begin{tabular}{llllll}
\hline \multirow{2}{*}{ Parameter } & Dry matter & Nitrogen & & \\
\cline { 3 - 6 } & & $\begin{array}{l}\text { From } \\
\text { basal N }\end{array}$ & $\begin{array}{l}\text { From } \\
\text { topdressed N }\end{array}$ & $\begin{array}{l}\text { Subtotal from } \\
\text { N fertilizer }\end{array}$ & $\begin{array}{l}\text { From soil } \\
\text { indigenous N }\end{array}$ \\
\hline Post-anthesis accumulation & $0.996^{* *}$ & 0.293 & 0.576 & 0.606 & $0.849^{*}$ \\
Remobilization amount & $0.960^{* *}$ & $0.916^{*}$ & $0.818^{*}$ & 0.798 & $0.857^{*}$ \\
\hline
\end{tabular}

$*$ and $* *$ are significantly correlation at $5 \%$ and $1 \%$ level.

\subsection{Nitrogen Utilization Efficiency}

For $\mathrm{N}$ utilization efficiency, similar trends occurred among treatments across both seasons (Table 6). Increasing $\mathrm{N}$ rate decreased $\mathrm{N}$ agronomic efficiency (NAE), $\mathrm{N}$ physiological efficiency (NPE) and fertilizer $\mathrm{N}$ (basal $\mathrm{N}$, topdressing $\mathrm{N}$ and total fertilizer $\mathrm{N}$ ) recovery efficiency (NRE). In contrast, increasing seeding rate increased NAE and NRE, but decreased NPE. Top-dressed N recovery efficiencies were 59\% in 2008-2009 and 53\% in 2009-2010, and basal $\mathrm{N}$ recovery efficiencies were $45 \%$ and $15 \%$, indicating significantly higher top-dressed $\mathrm{N}$ than basal $\mathrm{N}$ utilization. There was significant year variation between the two growth seasons, which NPE, NRE and NPE was lower in 2008-2009 than 2009-2010, but an oppisite was ture for NRE.

Table 6. Nitrogen utilization efficiency of winter wheat as affected by nitrogen fertilization and seeding rate.

\begin{tabular}{|c|c|c|c|c|c|c|}
\hline \multirow{2}{*}{ Growth season } & \multirow{2}{*}{ Treatment } & \multirow{2}{*}{$\begin{array}{l}\text { NAE } \\
\left(\mathrm{kg} \mathrm{kg}^{-1}\right)\end{array}$} & \multirow{2}{*}{$\begin{array}{l}\text { NPE } \\
\left(\mathrm{kg} \mathrm{kg}^{-1}\right)\end{array}$} & \multicolumn{3}{|l|}{ NRE (\%) } \\
\hline & & & & Basal N & Topdressed N & Fertilizer $\mathbf{N}$ \\
\hline \multirow[t]{6}{*}{$2008 \sim 2009$} & Nitrogen rate & & & & & \\
\hline & N150 & $14.1 \mathrm{a}$ & $29.9 a$ & $45.8 \mathrm{a}$ & $61.3 \mathrm{a}$ & $53.5 \mathrm{a}$ \\
\hline & $\mathrm{N} 225$ & $12.2 \mathrm{~b}$ & $26.5 b$ & $41.9 b$ & $56.4 \mathrm{~b}$ & $49.2 b$ \\
\hline & Seeding rate & & & & & \\
\hline & D150 & $12.4 \mathrm{a}$ & $27.0 \mathrm{~b}$ & $39.8 \mathrm{c}$ & $57.2 \mathrm{a}$ & $48.5 b$ \\
\hline & D300 & $13.8 \mathrm{a}$ & $29.1 \mathrm{a}$ & $46.7 \mathrm{a}$ & $59.0 \mathrm{a}$ & $52.9 \mathrm{a}$ \\
\hline F-value & $\mathrm{N} \times \mathrm{D}$ & 0.2 & 0.1 & 2.7 & 1.3 & 2.8 \\
\hline \multirow[t]{6}{*}{ 2009 2010 } & Nitrogen rate & & & & & \\
\hline & N150 & $14.9 \mathrm{a}$ & $43.3 \mathrm{a}$ & $16.2 \mathrm{a}$ & $55.0 \mathrm{a}$ & $35.6 \mathrm{a}$ \\
\hline & $\mathrm{N} 225$ & $12.1 \mathrm{~b}$ & $32.5 b$ & $14.8 \mathrm{a}$ & $51.6 \mathrm{~b}$ & $33.2 \mathrm{a}$ \\
\hline & Seeding rate & & & & & \\
\hline & D225 & $13.5 \mathrm{a}$ & $36.2 b$ & $15.5 \mathrm{ab}$ & $54.2 \mathrm{a}$ & $34.9 \mathrm{a}$ \\
\hline & D300 & $13.5 \mathrm{a}$ & $34.1 b$ & $17.1 \mathrm{a}$ & $55.0 \mathrm{a}$ & $36.1 \mathrm{a}$ \\
\hline \multirow[t]{2}{*}{ F-value } & $\mathrm{N} \times \mathrm{D}$ & 0.6 & 0.6 & 0.0 & 0.3 & 0.4 \\
\hline & Year & 0.4 & $29.4 * *$ & $3176.0 * *$ & $39.0 * *$ & $1037 * *$ \\
\hline
\end{tabular}

Means in each column and for each year followed by the same letter are not significantly different at $5 \%$ level. * and ** are significantly different at $5 \%$ and $1 \%$ level. NAE: nitrogen fertilizer agronomic efficiency; NPE: nitrogen physiological efficiency; NRE: fertilizer-N recovery efficiency. 


\section{Discussion}

\subsection{Yield and Its Components}

Maximum grain yield results from an optimum balance of three yield components: (i) the number of spikes per unit area, (ii) the number of kernels per spike and (iii) the weight of kernels [7, 13]. These yield components have interdependent action and are able to partially compensate for one another in order to stabilize yield as cultural or climatic conditions change. Rice-wheat rotation system is the main cereal production system on Yangtze Plain (China), increasing the yield of rice and wheat depends on the appropriate variety, planting time, soil tillage, large input of inorganic nitrogen fertilizer, water and nitrogen management. Rieger et al. [4] showed that the early growth and development of wheat under no-tillage treatment was slower, and the grain yield reduced by $3 \%$ compared with the conventional tillage. Therefore, increasing $\mathrm{N}$ management on different soil tillage was a key to increasing land productivity and economic sustainability [18]. However, in the present study, grain yield increased with increasing $\mathrm{N}$ rate from 0 to $225 \mathrm{~kg} \mathrm{ha}^{-1}$, which related to an increase in the number of spikes per unit area and kernels per spike; whereas grain size decreased, which was consistent with previous studies [9].

Generally, low seed rates increase the number of spikes produced by each plant, the weight of single spikes and the number of kernels per spike, but decrease the number of spikes per unit area [19]. Compared to the other yield components, kernel weight was found to be either decreased, or increased or unaffected in response to increase of seeding rate $[7,13]$. However, Wood et al. [11] found that grain yield of wheat was higher with 250 than 350 seeds $\mathrm{m}^{-2}$ due to a higher number of grains per spike and higher mean kernel weight. However, in the present study, the increase in seeding rate from 150 to 225 seeds $\mathrm{m}^{-2}$ increased grain yield because of a higher number of spikes per unit area and leaf area index (LAI). Lower seed rates produced a higher number of kernels per spike, photosynthetic rate (Pn) and chlorophyll content (SPAD), but they could not compensate for a low spike number. However, there was no significant difference in grain yields between D225 and D300 in the present study, which indicated that higher than 225 seed $\mathrm{m}^{-2}$ could increase inter-plant competition for light, water and nutrients, and could not improve grain yield.

\subsection{Dry Matter Accumulation and Remobilization}

In winter wheat, increasing $\mathrm{N}$ fertilization could promote accumulation and remobilization of photosynthates [16], but heavy use of $\mathrm{N}$ fertilizer delays senescence, resulting in substantial amounts of non-structural carbohydrates left in the straw leading to reduced grain yield [20]. In the present study, post-anthesis dry matter accumulation and remobilization increased with increasing $\mathrm{N}$ rate, but remobilization efficiency and the contribution of dry matter remobilization to grain yield decreased, which showed photosynthate in vegetative organs tend to transfer to grain under $\mathrm{N}$ deficit [21].

Increasing the seeding rate increased post-anthesis accumulation of dry matter and its remobilization from above-ground parts to grain yield, probably related to higher photosynthetic area, and therefore higher light interception by the canopy in higher plant densities [22]. There was a high positive correlation between grain yield and either post-anthesis accumulation of dry matter or its remobilization (Table 5), also explained increase of grain yield with increasing seeding rates. In other studies, dry weight of above-ground parts at anthesis also increased with higher seeding rate, thus increasing a potential pool to be remobilized [7, 13], that might also explain why remobilization amount was higher at the higher seeding rates. According to Arduini et al. [7], the contribution of pre-anthesis assimilates to grain may be crucial for maintaining grain yield when conditions become adverse for photosynthesis and mineral uptake during grain filling. In the present research, the contribution of dry matter remobilization to grain yield (CDMRG) was higher in D225 and D300 than D150. However, the remobilization efficiency of dry matter was about $20 \%$ in all treatments, and CDMRG was about $30 \%$ in both growing seasons, which were similar to Fang et al. [13].

\subsection{Nitrogen Remobilization and Utilization}

The highest $\mathrm{N}$ accumulation at anthesis and maturity, post-anthesis $\mathrm{N}$ accumulation and $\mathrm{N}$ remobilization occurred at the highest $\mathrm{N}$ rate due to higher dry matter yield and $\mathrm{N}$ concentration [21], with the highest plant density due to higher dry matter [7]. At the same $\mathrm{N}$ rate, higher basal $\mathrm{N}$ and top-dressed $\mathrm{N}$ uptake with increased seeding rate resulted in higher $\mathrm{N}$ utilization efficiency (Table 4 and Table 6).

Total $\mathrm{N}$ accumulation before anthesis and $\mathrm{N}$ remobilization were higher than $\mathrm{N}$ accumulation after anthesis (Table 3 and Table 4), an observation consistent with previous research [23]. There were, however, differences in $\mathrm{N}$ uptake and remobilization among different $\mathrm{N}$ sources. According to Wang and $\mathrm{Yu}$ [24], uptake and remobilization of $\mathrm{N}$ were always higher for soil $\mathrm{N}$ than fertilizer $\mathrm{N}$. However, in the present study, $\mathrm{N}$ uptake from fertilizer was higher than that from soil in 2008-2009 growing season; whereas N remobilization from fertilizer $\mathrm{N}$ was higher than soil $\mathrm{N}$ in both growing seasons. Different climate conditions, soil type, soil fertility and $\mathrm{N}$ application might have been responsible for the inconsistent results [25]. Regarding fertilizer N, both $\mathrm{N}$ uptake and remobilization were higher from top-dressed than basal $\mathrm{N}$, similarly to the report by Shi et al. [25]; the reason might be connected to top-dressed $\mathrm{N}$ being applied in the intensive growth period of winter wheat. After anthesis, it was found that $\mathrm{N}$ uptake from soil was higher than that from fertilizer in all treatments in both growing seasons, indicating that post-anthesis $\mathrm{N}$ uptake was dominated by soil $\mathrm{N}$, possibly related to early application of $\mathrm{N}$, which leached or loss through $\mathrm{N}_{2} \mathrm{O}$ if anaerobic. 
$\mathrm{N}$ remobilization efficiency represents a measure of the crop ability to remove $\mathrm{N}$ from vegetative tissues. When $\mathrm{N}$ uptake after anthesis is not maintained, and mobilization of $\mathrm{N}$ from vegetative tissues was excessive, causing early senescence and diminishing photosynthetic activity [26], thus increased remobilization efficiency. However, Muurinen et al. [27] found that at higher $\mathrm{N}$ rates, there was higher $\mathrm{N}$ remobilization efficiency. In the present study, remobilization efficiency and CNRG of total $\mathrm{N}$ decreased with increasing $\mathrm{N}$ rate and decreasing seeding rate, and there were no significant differences in a majority of treatments, similarly to Ercoli et al. [14] and Arduini et al. [7]. Remobilization efficiency of fertilizer $\mathrm{N}$ and its contribution to grain $\mathrm{N}$ content increased with increasing $\mathrm{N}$ rate, possibly due to a greater amount of fertilizer $\mathrm{N}$ being remobilized; whereas the opposite occurred for soil N. In all treatments, remobilization efficiency and CNRG were significantly higher for fertilizer than soil $\mathrm{N}$ in both growing seasons. For fertilizer N, the values were higher for top-dressed than basal $\mathrm{N}$, an observation consistent with Shi et al. [25]. Correlation analysis indicated that both increased remobilization of fertilizer $\mathrm{N}$ (basal and top-dressed) and post-anthesis accumulation of soil $\mathrm{N}$ helped improve grain yield.

Grain yield of winter wheat on Yangzte River Plain is usually affected by rainfall often resulting in waterlogging [28]. Waterlogging affected nutrient uptake, transfer and distribution in roots, reduced photosynthetic rate of leaves, and finally decreased dry matter accumulation and grain yield. In the present study, there were significant year-by-year variations in grain yield and its components, dry matter accumulation and remobilization, $\mathrm{N}$ uptake and utilization, which might have been related to variable rainfall across the two seasons. In particular, lower basal $\mathrm{N}$ recovery in 2009-2010 was related to high rainfall in November and December 2009, which possibly led to increased nitrogen fertilizer leaching in early growth stage. When winter wheat was booting and filling, excessive rainfall in March and April could be responsible for yield reduction [29].

\section{Conclusions}

Grain yield increased with increasing $\mathrm{N}$ rate and the optimum seeding rate $\left(225 \mathrm{seed} \mathrm{m}^{-2}\right)$. A grain yield increase was due to higher values for number of spikes per area, LAI, and post anthesis accumulation of dry matter, with higher biomass and $\mathrm{N}$ uptake at anthesis providing a basis for higher remobilization of resources to the developing grain. Fertilizer $\mathrm{N}$ remobilized to grain more easily than soil $\mathrm{N}$, and top-dressed $\mathrm{N}$ remobilized to grain more easily than basal $\mathrm{N}$. Remobilization of fertilizer $\mathrm{N}$ and post-anthesis accumulation of soil $\mathrm{N}$ were positively correlated with grain yield. There were significant variations between years in grain yield and components, dry matter accumulation and remobilization, $\mathrm{N}$ uptake and utilization, which could be related to variable rainfall across the two seasons.

\section{Acknowledgements}

We acknowledge generous financial support from the National Rape Industry Technology System (CRAS-12) and the National Natural Science Foundation of China (Grant No. 31401335).

\section{References}

[1] Cai, A. D., Zhang, W. J., Xu, M. G., Wang, B. R., Wen, S. L., Shah, S. A. A. Soil fertility and crop yield after manure addition to acidic soils in South China [J]. Nutrient Cycling in Agroecosystems, 2018, 111 (1): 61-72.

[2] Shi, Z. L., Li, D. D., Jing, Q., Cai, J., Jiang, D., Cao, W. X., Dai, T. B. Effects of nitrogen applications on soil nitrogen balance and nitrogen utilization of winter wheat in a rice-wheat rotation [J]. Field Crops Research, 2012, 127: 241-247.

[3] Ruiz-Colmenero, M., Bienes, R., Marques, M. J. Soil and water conservation dilemmas associated with the use of green cover in steep vineyards [J]. Soil Tillage Resarch, 2011, 117: 211-223.

[4] Rieger, S., Richner, W., Streit, B., Frossard, E., Liedgens, M. Growth, yield, and yield components of winter wheat and the effects of tillage intensity, preceding crops, and $\mathrm{N}$ fertilization [J]. European Journal of Agronomy, 2008, 28: 405-411.

[5] Bellido, R. J. L., Bellido, L. L., Castillo, J. E., Bellido, F. J. L. Chickpea response to tillage and soil residual nitrogen in a continuous rotation with wheat II. Soil nitrate, N uptake and influence on wheat yield [J]. Field Crops Research, 2004, 88: 201-210.

[6] Fan, J. L., Luo, R. Y., Liu, D. Y., Chen, Z. M., Luo, J. F., Boland, N., Tang, J. W., Hao, M. D., Mcconkey, B., Ding, W. X. Stover retention rather than no-till decreases the global warming potential of rainfed continuous maize cropland [J]. Field Crops Research, 2018, 219 (15): 14-23.

[7] Arduini, I., Masoni, A., Ercoli, L., Mariotti, M. Grain yield, and dry matter and nitrogen accumulation and remobilization in durum wheat as affected by variety and seeding rate $[\mathrm{J}]$. European Journal of Agronomy 2006, 25: 309-318.

[8] Li, P. C., Dong, H. L., Liu, A. Z., Liu, J. R., Sun, M., Wang, G. P., Liu, S. D., Zhao, X. H., Li, Y. B. Effects of planting density and nitrogen fertilizer interaction on yield and nitrogen use efficiency of cotton [J]. Transactions of the Chinese Society of Agricultural Engineering, 2015, 31 (23): 122-130.

[9] Cao, Q., He, M. R., Dai, X. L., Men, H. W., Wang, C. Y. Effects of interaction between density and nitrogen on grain yield and nitrogen use efficiency of winter wheat [J]. Plant Nutrition and Fertilizer Science, 2011, 17(4): 815-822.

[10] Carr, P. M., Horsley, R. D., Poland, W. W. Tillage and seeding rate effects on wheat cultivars. I. Grain production [J]. Crop Science, 2003, 43: 202-209.

[11] Wood, G. A., Welsh, J. P., Godwin, R. J., Taylor, J. C., Earl, R., Knight, S. M. Real-time measures of canopy size as a basis for spatially varying nitrogen applications to winter wheat sown at different seed rates [J]. Biosystems Engineering 2003, 84: 513531. 
[12] Zhang, J., Wu, T. H., Dai, X. L., Wang, X. Z., Li, H. M., Jiang, M. Y., He, M. R. Effects of plant density and nitrogen level on nitrogen uptake and utilization of winter wheat $[\mathrm{J}]$. Chinese Journal of Applied Ecology, 2017, 26 (6): 1727-1734.

[13] Fang, Y., Xu, B. C., Turnerd, N. C., Li, F. M. Grain yield, dry matter accumulation and remobilization, and root respirationin winter wheat as affected by seeding rate and root pruning $[\mathrm{J}]$. European Journal of Agronomy, 2010, 33: 257-266.

[14] Ercoli, L., Lulli, L., Mariotti, M., Masoni, A., Arduini, I. Post-anthesis dry matter and nitrogen dynamics in durum wheat as affected by nitrogen supply and soil water availability [J]. European Journal of Agronomy 2008, 28: 138-147.

[15] Zhang, S., Shao, Y. H., Shi, Z. L., Tian, Z. W., Jiang, D., Dai, T. B. Effect of magnesium fertilization on dry matter accumulation and translocation and grainfilling under post-anthesis heat stress in winter wheat [J]. Journal of Triticeae Crops, 2017, 37 (7): 963-969.

[16] Zhang, J. H., Liu, J. L., Zhang, J. B., Zhao, F. T., Cheng, Y. N., Wang, W. P. Effects of nitrogen application rates on translocation of dry matter and nitrogen utilization in rice and wheat [J]. Acta Agronomica Sinica, 2010, 36: 1736-1742.

[17] Cookson, W. R., Rowarth, J. S., Cameron, K. C. The fate of autumn-, late winter- and spring-applied nitrogen fertilizer in a perennial ryegrass (Lolium perenne L.) seed crop on a silt loam soil in Canterbury [J]. New Zealand. Agriculture, Ecosystems and Environment, 2001, 84: 67-77.

[18] Wu, X. L., Li, C. S., Tang, Y. L., Liu, Y. B., Li, B. Q., Fan, G. Q. Xiong, T. Effect of nitrogen management modes on grain yield, nitrogen use efficiency and light use efficiency of wheat $[\mathrm{J}]$. Chinese Journal of Applied Ecology, 2017, 28 (6): 1889-1898.

[19] Fang, Q., Wang, H. G., Ma, B. W., Li, D. X., LI, R. Q., Li, Y. M. Effect of planting density and nitrogen application rate on population quality and yield formation of super high-yielding winter wheat [J]. Journal of Triticeae Crops, 2015, 35 (3): 364-371

[20] Ma, D. H., Zhao, C. X., Wang, Y. F., Wu, G., Lin, Q. Effects of nitrogen fertilizer rate and post-anthesis soil water content on photosynthetic characteristics in flaa leaves and yield of wheat [J]. Acta Ecologica Sinica, 2008, 28 (10): 4896-4901.
[21] Dordas, C. Dry matter, nitrogen and phosphorus accumulation, partitioning and remobilization as affected by $\mathrm{N}$ and $\mathrm{P}$ fertilization and source-sink relations [J]. European Journal of Agronomy, 2009, 30: 129-139.

[22] Hu, F. L., Guo, D. L., Gao, J., Lu, H. D., Zhang, R. H., Xue, J. Q. Effects of planting densities on dry matter and nitrogen accumulation and grain yield in spring maize [J]. Acta Agriculturae Boreali-occidentalis Sinica, 2013, 22 (6): 81-102.

[23] Mi, G. H., Liu, J. A., Chen, F. J., Zhang, F. S., Cui, Z. L., Liu, X J. Nitrogen uptake and remobilization in maize hybrids differing in leaf senescence [J]. Plant Nitrition, 2002, 92: 6869.

[24] Wang, X. Y., Yu, Z. W. Effect of irrigation rate on absorption and translocation of nitrogen under different nitrogen fertilizer rate in wheat [J]. Scientia Agricultura Sinica, 2008, 41: 30153024.

[25] Shi, Z. L., Jing, Q., Cai, J., Jiang, D., Cao, W. X., Dai, T. B. The fates of ${ }^{15} \mathrm{~N}$ fertilizer in relation to root distributions of winter wheat under different $\mathrm{N}$ splits [J]. European Journal of Agronomy, 2012, 40: 86- 93.

[26] Ding, J. F., Cheng, Y. M., Huang, Z. J., Li, C. Y., Guo, W. S., Zhu, X. K. Difference analysis of post-anthesis matter production and senescence characteristics among different nitrogen efficiency populations in wheat following rice $[\mathrm{J}]$. Scientia Agricultura Sinica, 2015, 48 (6): 1063-1073.

[27] Muurinen, S., Kleemola, J., Peltonen-Saito, P. Accumulation and translocation of nitrogen in spring cereal cultivars differing in nitrogen use efficiency [J]. Agronomy Journal, 2007, 99: 441-449.

[28] Wu, X. L., Tang, Y. L., Li, C. S., Wu, C., Huang, G. Effect of waterlogging at different growth stages on flag leaf chlorophyll fluorescence and grain-filling properties of winter wheat $[\mathrm{J}]$. Chinese Journal of Eco-Agriculture, 2015, 23: 309-318.

[29] Fan, X. M., Jiang, D., Dai, T. B., Jing, Q., Cao, W. X. Effects of nitrogen on grain yield and quality in wheat grown under drought or waterlogging stress from anthesis to maturity $[\mathrm{J}]$. Journal of Plant Ecology, 2006, 30: 71-77. 